\title{
ENACTING OUTSOURCING: AN INNOVATION PROCESS PERSPECTIVE
}

\author{
BENEDIKTE BORGSTRÖM* \\ SUSANNE HERTZ** \\ *bobe@ihh.hj.se \\ **hesu@ihh.hj.se \\ Department of Marketing and Logistics \\ Jönköping International Business School \\ Sweden
}

\begin{abstract}
Much research has been done on outsourcing. However, we still know little about outsourcing based on a social process view on innovation. Outsourcing is an innovation as a logistics-related process that is perceived as new by the adopter. We will explore and analyse an outsourcing idea, its development and implementation, from an innovation perspective. The development is studied in a qualitative, long-term process study. The analysis draws on Hoholm's (2009) model of innovation processes. It extends the applicability of this innovation model and its methodology of following the action into logistics and supply chain management (SCM) research. The outsourcing process is an innovation that develops in a rational way based on the incremental process because of its actor-network and simultaneous reflection. Interactions and confrontations come about because of involved contrary forces such as competing objectives. The model explains the practice of SCM innovation and increases the understanding of dynamics and complexity. The process study brings insights to cause-effect relations in the development of outsourcing that are consequential to innovative logistics and SCM.
\end{abstract}

\section{INTRODUCTION}

Can outsourcing be explained by its conceptual puzzle pieces? Outsourcing is a phenomenon which has been widely recognised in practice as well as in theory. The outcome of outsourcing affects strategic development and leads to changes in internal and external relations, meaning that it will affect the organisation in the long term as well as in its dayto-day operations (Moses, 2009). The theoretical literature has explained outsourcing with variable-based as well as contextual studies in order to learn of its properties and the nature of adherent problems and opportunities. Still, most companies currently lack the understanding, capability or willingness to operate an integrated and coordinated outsourcing strategy (Trent \& Monczka, 2005). The involved dynamics and complexity by 'hidden' interdependencies create problems in the outsourcing process (Agndal \& Nordin, 2009). Thus, despite the insights into conceptual properties of outsourcing, its development is explained only partially. 
Outsourcing is a part of strategic development. It is an innovative idea for business model reconstruction (Kuratko \& Audretsch, 2009), where sometimes logistics is the content of outsourcing and sometimes logistics influences the outsourcing process. Logistics innovation has gained a foothold in logistics and supply chain management (SCM) literature as a perspective of what value logistics providers can deliver, for example, in an outsourcing process. Logistics and SCM innovation is also seen as a capability to foster innovations in firms and in supply chains. It is the innovative process rather than simply an innovation that distinguishes successful innovating firms (Flint, Larsson, Gammelgaard \& Mentzer, 2005). However, most outsourcing process models are prescriptive categorisers (e.g. Trent \& Monczka, 2003) rather than explanatory and, in practice, general outsourcing models are not directly applicable (Nordigården, 2007). There is a gap in the literature about how firms should go about outsourcing; there is a need to address the relevance in research, in terms of setting findings in a social setting of action. Flint's et al. (2005) call for more research, especially relating to social aspects: To what extent should logistics innovation be formally managed versus being allowed to spontaneously emerge or even be informally managed? And, what aspects of social interaction and relationships intrude upon the innovation process if logistics innovation is seen as a social process? But also, where are the key obstacles to being innovative in the logistics context? And finally, how are firms managing supply chain learning? These questions address, in turn, governance of the logistics innovation process, the social situatedness of the process and social output.

The idea and development of strategic outsourcing might be more or less planned and the raison d'être might be ambiguous (Mintzberg \& Waters, 1985; Mintzberg, 1994), and the outcome is indeterminate (Hoholm, 2009). If we assume that uncertainty and complexity are important in explaining outsourcing development, then it is appropriate to use the methodological and analytical tools of practice theory, such as actor-network theory or social practice theory of learning and organisational development to increased relevance (Gherardi, 2009; Hoholm, 2009), which to our knowledge is a new perspective in logistics and SCM research.

We will explore and analyse an outsourcing idea, its development and implementation, from an innovation perspective.

The analysis will draw on a model by Hoholm (2009) of how an innovation process should be studied as interaction between processes of mobilisation and exploration (although interconnected and heterogeneous). The paper starts with the theory of outsourcing, followed by the innovation process model. Then, a qualitative case study of an outsourcing project is described and analysed. Finally, the outcome of the specific project is explained with a discussion of the methodological implications of a practice theory of logistics innovations. 


\section{OUTSOURCING: AN INNOVATION PROCESS}

By definition, outsourcing refers to the purchasing from an external supplier of a function previously done within the company (Axelsson \& Wynstra, 2002). Outsourcing is conceptualised by context or by different factors describing the outcome (Moses, 2009) and most acknowledge the great difficulties that are related to outsourcing (Nordigården, 2007; Agndal \& Nordin, 2009; Moses, 2009) and its potential for business model reconstruction (Kuratko \& Audretsch, 2009).

By definition, innovation, in the broad Schumpeterian view that Flint et al. (2005) adopt, embraces innovation occurring within product development, services, processes, or any social system. 'Innovation is an idea, practice, or object that is perceived as new by an individual or other unit of adoption' (Rogers, 1995: 11). Logistics innovation is, according to Flint et al., any logistics-related service from the basic to the complex that is seen as new to a particular audience; innovations might improve operational efficiency or innovations might better serve customers. Flint et al. (2005) were interested in externally focused customerservice innovations. They studied logistics innovations, based on perceptions of leaders (logistics service provider firms and logistics business functions) in seven organisations. The resulting model of activities in logistics innovation processes include: 1) setting a stage for innovation; 2) identifying clues to shifts in what customers value; 3) negotiating, clarifying and reflecting upon insights; and 4) managing inter-organisational learning (Figure 1). Importantly, Flint et al. engage the social aspects of innovation and highlight the role of interactions and reflexivity among the innovating actors as much as innovation stages and innovations themselves.

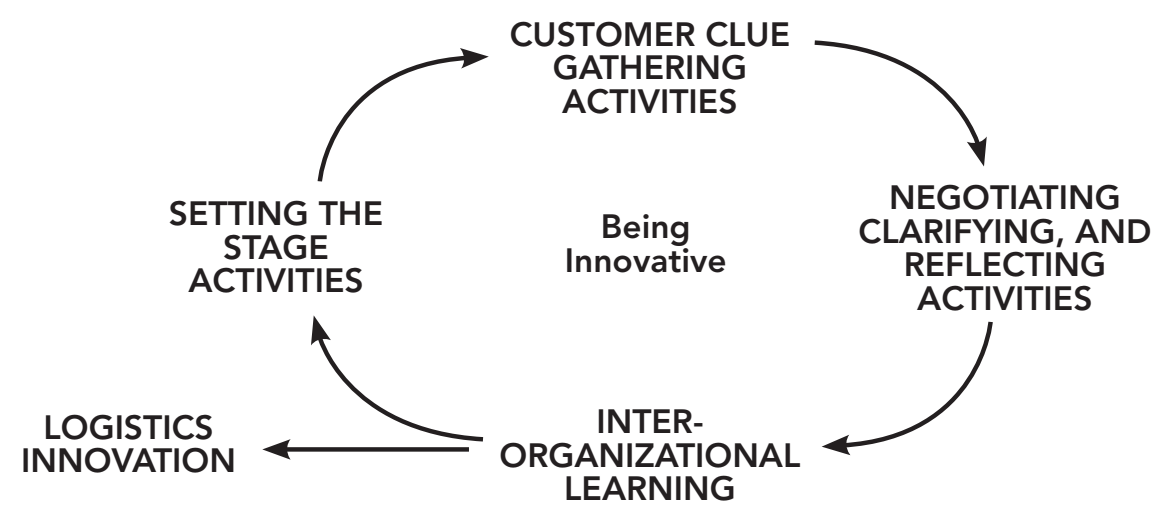

Figure 1: A logistics innovation process (Flint et al., 2005: 127)

Social aspects are often downplayed in logistics and SCM literature. But Flint et al. (2005) specifically discuss logistics innovation as inspired by actors responding to and interpreting a dynamic environment, continuously reflecting on their interpretations, the interpretations of others, and responses by others to their actions (i.e. innovations). Most 
firms lack knowledgeable interaction with the outsourcing strategy (Trent \& Monczka, 2005). Outsourcing comprises dynamic enablers and hinderers (Agndal, 2004; Agndal \& Nordin, 2009), which are contrary forces of innovation (Hoholm, 2009).

Hoholm uses the methodological and analytical tools of actor-network theory in the study of an innovation process from idea to commercialisation, and 'followed the actors' as they strove to move the innovation towards realisation. Hoholm suggests that innovation processes are characterised by uncertainty and controversy, in particular in the interaction between the mobilising of actor-networks and the exploration of knowledge. Thus, the mobilisation is in line with Flint et al.'s first, second and third aspects of the innovation process (above) and the knowledge exploration is in line with Flint et al.'s learning aspect. The value of Hoholm's practice lens in this discussion is in the serious interest of action, which includes that uncertainty and controversy increase because the innovation process is situated within a network of interconnected processes. Thus, the innovation process is interconnected with other processes (Hoholm, 2009) and is also cyclical within the activities of settling, understanding, developing and learning (Flint et al., 2005). The Flint et al. model of innovative processes is compatible with the Hoholm model but where the former focuses on the organisation's innovative capability the latter focuses on innovation development. This addresses Trent and Monczka's (2005) concern that, in addition to capability, willingness and understanding are needed in the outsourcing process if it is to achieve excellence. Putting the approaches side by side, the Flint et al. model seems to be a typical process model (Pettigrew, 1997) while the Hoholm model is a process model based on practices (see e.g. Schatzki, 2000; Gherardi, 2009). A process study typically depicts a set of variables in order to gain in-depth knowledge about cause-effect relationships while the practice study is situated in the 'happening' in order to identify such relationships with their complexity, dynamics and effects. Thus, the practice study aims to understand what is happening with situational effects.

Consequently, if innovation processes and logistics innovation processes are seen as new ideas that develop, it is reasonable to suggest that an outsourcing idea's development could be understood differently, i.e. by its situated development. A practice perspective, such as actor-network theory that follows the action, is a means to accomplish that. A practice study might be differentiated from grounded theory research in that it takes the idea as a starting point and follows it through its transformation over time.

\section{AN ANALYTICAL SCHEME OF INNOVATION PROCESSES}

The actor-network approach has been applied to a variety of settings in research since the early work in the laboratory by Latour (1987). The approach has been successfully used to understand how creation and change such as new ideas, new markets or new products are 
developing (Czarniawska, 2004; Helgesson, Kjellberg \& Liljenberg, 2004) and shows how interpretations, translations, negotiations and conflicts are influencing technology, economic and social development. The analytical scheme of innovation processes by Hoholm (2009) is a thesis about the development of innovation processes based on a rich empirical study (see Figure 2) and aims for the practice of industrial innovation.

Figure 2 conceptualises the innovation processes as ongoing and transforming with new knowledge and with a further actor-network as a dual process: it is a process of knowledge exploration and a process of mobilising actor-networks that are interacting. Knowledge exploration is an iterative process where actors' propositions of the history, the present and the future are reinforced or transformed. Tensions between belief in innovation and reality develop by the 'reality', i.e. what actually happens. Involved parties form development (some actors are influential in one phase but less influential in another), involved technologies (how these are combined and utilised in this innovation process and in other related processes), and economic relations (a low-cost budget, for example). Mobilising actor-networks typically involves politics. Presenting, convincing, forcing and negotiating are the mobilising actions that formulate and re-formulate the innovation.

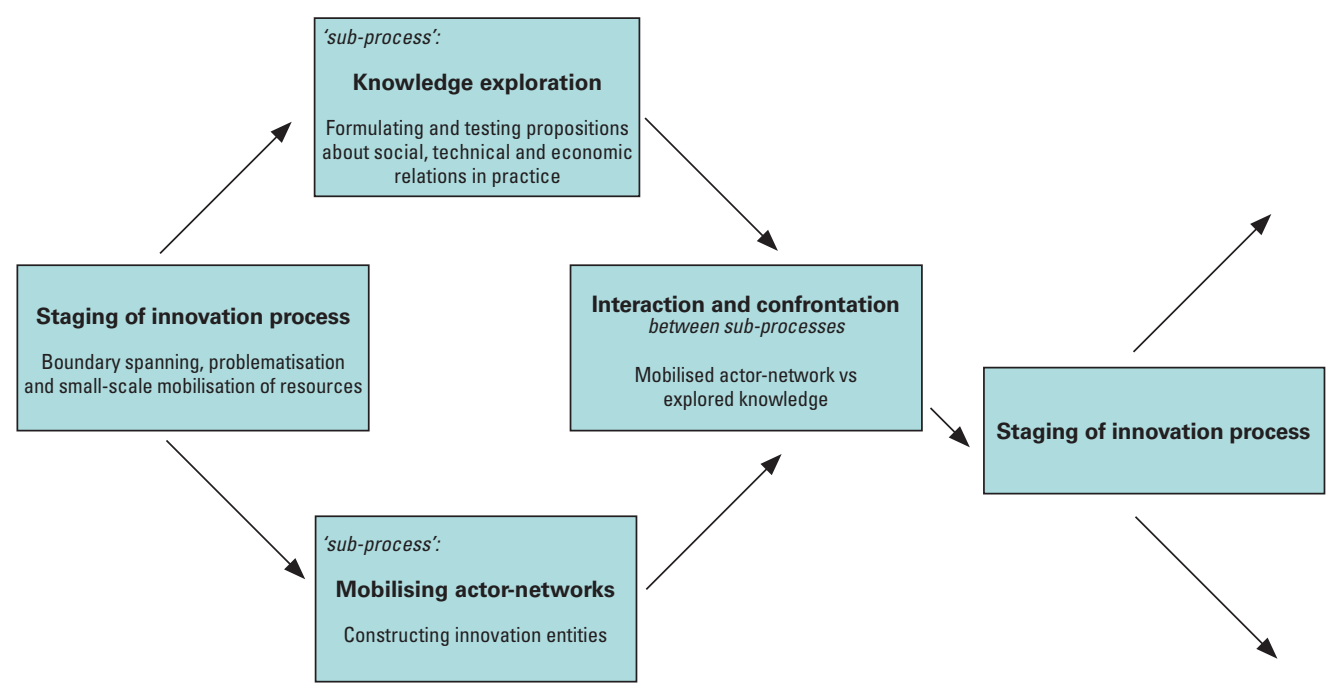

Figure 2: An interactive process model of how to study innovation processes as interaction between processes of mobilisation and exploration in an innovation process (adapted from Hoholm, 2009: 238)

Staging of innovation processes is caused by a happening, a question, an incidence or a plan. It is an idea that comes from an entrepreneurial spanning of boundaries in creating something new. The objectives might be to improve operational efficiency or to better serve customers; it depends on the problematisation and the first small-scale mobilisation of resources. After the staging there is the problem of how to mobilise the time, space, actors and resources to start the exploration and realisation of the innovation. The innovators 
repeatedly need to mobilise support and more resources from their partners or find new partners. Thus, mobilising actor-networks is a pragmatic process of making use of involved parties and resources in order to expand the actor-network and the access to further resources. The question of 'what is in it for me' is revisited. It is an ongoing construction of meaning and arguments in order to mobilise power over resources and decisions.

Simultaneously, knowledge exploration is ongoing whether or not the ideas hold in reality. The ideas are propositions that need reformulation and tests based on the mobilised actornetwork. The mobilised actor-network has social, technical and economical relations that impact the development. The knowledge exploration is a two-step process of creatively imaging relations and testing these in practice. This testing changes the innovation, often in unforeseen ways. The processes of mobilisation of actor-networks and exploration of knowledge sometimes interact and confront each other (Hoholm, 2009). For example, when allies in the actor-network become impatient, the exploration process may be confronted for its lack of progress or its departure from the original idea. Similarly, discoveries and knowledge generated in the exploration process may challenge the mobilised actornetwork and change their interests and participation. Both ways in which such interactions and confrontations come about and their results actually reveal some of the dynamics of innovation processes; in the parts where new meaning is negotiated, choices have to be made and new directions of action are taken (Hoholm, 2009).

Mobilising actor-networks and knowledge exploration have different outcomes in the innovation process. Exploration/knowledge creation tends to increase uncertainty with new possibilities while mobilisation tends to reduce uncertainty as reality unfolds. Mobilisation is directed towards aligning interests and reducing risk, whereas exploration is directed towards formulating and testing propositions about reality (Hoholm, 2009: 249). The innovation process involves these two sub-processes that are based on opposing logics and thereby often conflict and challenge each other. For example, in order to enrol allies in the continued innovation process it is necessary to converge the idea on a number of aspects, and this will create a 'lock-in' for the remaining process. The 'lock-in' holds the exploration of the project within its limits. New elements (human or non-human) that are enrolled and mobilised influence the development.

In logistics and SCM innovation processes the innovation process cannot be isolated from other innovation processes in-house or in the supply network. It evolves with a set of interconnected and interacting processes that mutually influence each other. Parallel actor-networks might have aligned interests and sometimes one development takes over. In particular, new user-producer relationships are hard to establish during innovation. They will be fragile as long as tangled interests and resources are lacking and there might be little commitment from the new user. New allies might drop the innovation without warning and without risking much. 
The process model (Figure 2) is a simplification as it depicts one innovation process. At work, this process is situated in networks of interconnected innovation processes, where for example, the knowledge exploration in one gives an idea to another innovation process, influences the knowledge exploration in another process, and the mobilising process in yet another. A myriad of actor-networks might co-develop.

\section{RESEARCH DESIGN AND CASE STUDY}

\section{Outsourcing to China}

Before we go into the case of outsourcing the platform to advanced products, we will describe the background of the outsourcing and describe how the research project was done.

\section{The study}

Our research project was initiated in 2007, and the empirical description is based partly on real-time and partly on historical accounts. We ran the project from 2007 to 2009. In 2007 the focal company launched new A and B models and the sales peaked, which continued until the financial crisis in October 2008 when the sales dropped dramatically necessitating many lay-offs.

Our learning about the development stems from interviews in Sweden and in China with involved parties. Most of our empirical material relates to the supply side of our focal company, i.e. transporters, third party logistics providers, the supply network, and the focal company's purchasing function. The case is one specific outsourcing project. In many other case studies it is common to set a unit of analysis; in our methodological approach it is rather a question of following the action in the process (Kjellberg \& Andersson, 2003). The interviews totalled approximately 30 hours of interaction, which has been transcribed. In addition, secondary material such as interviews in newspapers, journals, and master/bachelor theses give insight into development in broader terms, such as press releases about product launches, lay-offs, comments on the market, and analyses of logistics and competencies. Managers involved in marketing, purchasing, product development and logistics, and production were interviewed in Sweden and also in China. The focal firm, suppliers and suppliers' suppliers were interviewed. All interviews started with a questionnaire consisting of open-ended questions. We also made company visits to offices, warehouses and factories in Sweden and China in several stages. The explorative purpose of the inductive study was facilitated by these multiple sources, because new and refined questions could be added (see also Flint et al., 2005) and theoretical literature could be brought in over time in an abductive way (Alvesson and Sköldberg, 2008). The data is situated (time and context) and not entirely reproducible because the development process changes with the situation. Instead it is possible to refine the insights and theoretical implications in other studies. 
During the study, interactions with involved parties provided valuable reflections of the interpretations. A limitation is the low degree of generalisation; insights from exploratory research inspire additional research and are of relevance to practitioners but are not generalisable in a statistical sense. Causalities in the process are stated but the relationship strength depends on the context.

The interpretation and analysis of the material has been done in four steps. A first analysis was done in the interview situation where the respondents were asked to develop some answers that we thought were interesting regarding the outsourcing idea, development and implementation. The second was refining the transcription by comments to the protocols and discussions in the research team. The third step was the writing of the case and illustrating the case in the next section. The fourth analysis depended on the theoretical framework used, which in this paper is outsourcing from an innovation perspective represented specifically by the conceptual model of innovation processes (Hoholm, 2009). In reality, much more complexity exists and making the case description read like a 'good' story is important in order to facilitate reflections. Interpretative theorising is taking surprises from the field material seriously (Alvesson \& Kärreman, 2007) and the 'good' story aims to create understanding of the social elements. Thereafter, further analysis of the outsourcing case as a logistics innovation process was facilitated.

\section{Case: Focal company background}

Our focal company is an original equipment manufacturer (OEM) that makes exclusive consumer machines. The branded machines (brand A and brand B) are well known for being technically advanced and for their high quality. Consumers buy them to be expert users; they also often invest in technique training, additional options and equipment, which is an important income stream to the OEM. Our focal company is a market-oriented company that has some experience of low-cost country sourcing. The former owner, Invest Kapital (a pseudonym), acquired brand B to achieve synergies, such as in production, between the brands $A$ and $B$.

A focused product development of a common platform for brand A and brand B opened up the possibility to scale advantages in production. In 2004, the management team of our focal company decided to move the production of components offshore to China, which they perceived as an innovative idea for reducing costs. Both brand A's and B's product base was the platform. Producing the platforms at one site facilitated cost advantages by economies of scale in production, and even more so in a low-cost country. The platform and components were already being produced in a low-cost east-European country but moving the production to China seemed to provide even lower costs and increased volume. In this phase of offshoring, the OEM was developing a Chinese supply network via an employee who had moved to China after which the OEM was acquired by Next Investor (a 
pseudonym). Next Investor owned C-Worldwide already, which was the biggest producer in the industry. Thus, C-Worldwide extended its portfolio of brand C, a mass-produced low-cost machine, with brands $A$ and $B$. Brand $C$ was mass produced in many sites globally and mass distributed. There were few synergies between A/B and C. In 2007, C-Worldwide decided to use their production facilities in China for A and B.

\section{Case: Development of the outsourcing project}

An outsourcing initiative to China is a decision that is well in line with other Swedish manufacturing firms' initiatives during the early 2000s. The change would obviously impact both the existing supply chains and be a reason to design new supply chains. We will illustrate the scenario by describing the development: A first phase of the OEM's own initiative and a second phase with the initiative imposed by Next Investor. These phases are a part of the outsourcing development.

\section{The first phase}

The problematisation started in the focal company, which develops innovative customeroriented machines. The OEM's market function is important for future survival. The supply base and purchasing function in the focal company is historically not a strategic function beyond quality and delivery. Sourcing is mainly operational in character. But, they do support the product development projects that are of more strategic importance by finding appropriate suppliers that manage their demands of quality and terms of delivery.

The focal company's new CEO wished to work strategically with the supply base in order to improve the time in the delivery process but more especially time in the productdevelopment process. He had experience of industrialising innovative technology products for lower costs from his earlier employment. The OEM's purchasing function worked to attain long-term relationships with suppliers. Otherwise they had to invest and teach the new supplier their demands with respect to quality and consistency in deliveries, which is an extensive task. In 2007, the OEM decreased the supply base to 150 from a previous 600 suppliers (of whom half were in Europe and half outside). Approximately 100 of these suppliers had unique competencies.

The objectives of the outsourcing varied. The first phase of outsourcing was a greenfield investment. The greenfield investment intended to outsource for lower costs. The plan was to take advantage of suppliers in China and gradually add more local suppliers and intermediates. They developed their outsourcing idea and were coordinated by the supply manager in China, whose role was to coordinate and engage the suppliers as they communicated in a more effective manner with each other in operational issues. 
Outsourced production related to other functions, such as purchasing and product development. The intent of local sourcing in China was challenged by interdependencies between our focal company's R\&D and suppliers. R\&D plays an important role in continuously developing successful innovative customer solutions. The demands of the Swedish R\&D were in many cases difficult to appreciate for a supply network in China. Some demands were implicit, some country-specific, and some supplier-specific in which common development differentiated the innovative products.

Then, as we will see in the next phase, the outsourcing process changed in 2007 with C-Worldwide's decision to involve their Chinese production site. This seemed to be in line with the Chinese sourcing decision that our focal company was already working on. The difference was how the global outsourcing happened. The Chinese production site of C-Worldwide, i.e. a sister firm to our focal company, was used for production. The sister company, a high-volume producer, was sceptical about the incoming low volumes and high technological demands of tolerances in the product. They were excellent in mass producing low-cost products but not in these high-end products. The platform was handled separately from the mass production. So, by means of this outsourcing process another path than that of widening the supply network of their own was emerging. The focal company had to cooperate closely with the sister company in China to make sure the product did not change characteristics. Instead of discussing low costs, the focal company was troubled by the politics of deciding where to produce, and considering what the consequences of production in China would imply in terms of their market offer.

\section{The next phase}

The outsourcing coordination was extensive. The OEM's local representative moved back to Sweden to facilitate the production transfer. Personnel from the production sites visited each other in order to facilitate learning. The OEM had too little production capacity and the Chinese sister company relieved the pressure to lower costs at the same time as increasing capacity. The Chinese sister company got the transferred production and the production knowledge was 'handed over'. The sister company was not willing to take an active part in development. They preferred to act in accordance with specified demands for quality and precision. Our focal company experienced lower costs but also many problems because the characteristics of the product changed. In addition, they now had to deal with a strong sister company which had a low degree of commitment to the outsourcing process.

The platform approach changed the sourcing situation, and so did the new owner. The platform was the base for more than ten different end products that could be outsourced to C's production facilities in China. It was important to keep some production in-house in order to learn from and experience new product introductions. The focal company sought suppliers based on supplier experience and know-how rather than transaction costs. In 
contrast, the Chinese production site's competence was related to low cost processes. The Chinese site was used for supplies but needed to rely to a great extent on the same sources as our focal company in order to manage product requirements. Thus, this was a new situation for both sites. The Chinese site was not satisfied with the role and function of the imposed supply network; traditionally they were heading for low costs and the new set of demands was alien to them. The Swedish site was not satisfied with all the extra work required in the production transfer and not happy with their role as a middleman between the old European suppliers and the Chinese production site. However, setting up and designing parallel and overlapping supply chains seemed to be possible despite strategic differences from the start. For our focal company, the outsourcing meant a huge investment of resources and uncertainty about the product characteristics, actual advantages in terms of lower costs and a risk of lost know-how of developing, producing and sourcing. The Chinese production site needed to engage in production with higher demands and set aside a minor part of its production resources for the 'special' production. Hence, they risked little by taking part in the development.

Despite extra logistics costs the outsourcing idea was thought of as advantageous. However, the new phase of the outsourcing (the involvement of C's Chinese production site) impacted the development: the technical and to some extent the physical processes were integrated and were functioning as intertwined processes. Because the technical development was kept in Sweden and some specific (sometimes Swedish) suppliers were involved, the product flow became complex and in need of close coordination. Our focal company had few incentives to take on this extra coordination for C's account, because the market had changed and they wanted to keep production in-house and enjoyed no incentives to develop the outsourcing further. The owner wanted to lower costs at the site. In addition, administrative routines of how to handle the new flows were uncertain. The production sites got a role as intermediates for some sourcing, which went beyond their normal working procedures. Our focal company's and the sister company's purchasing functions had different views of how to source (costs versus quality). Naturally, as the production sites were dependent on each other with regard to some sources, the divergent goals created tensions and circumscribed development. For example, it would be preferable to purchase some sourcing locally, and also such tasks needed to be as carefully transferred. The operational purchasing emerged and decisions were handled but the strategic purchasing decisions and coordination of the overlapping networks and similar kinds of issues were never on the agenda.

\section{Contrary forces}

The new owner's strategic decision to move our focal company's production offshore to the sister company was pivotal to the development. When Next Investor acquired our focal company it planned to sell the company in a few years' time. Outsourcing would lead to cost advantages and a better deal for Next Investor. The nitty-gritty of outsourcing, such as 
strategic coordination of sourcing, supply and transport were far from the top management agenda. The middle management at our focal company as well as at the sister company encountered and questioned problem areas such as cost vs quality, brand value over time due to country of origin, use of middlemen, local sourcing vs sourcing of expert producers, how to take advantage of the overlapping network, and the need to produce a high-end product at a low cost, but they did not consider coordinating these issues. As long as the production sites were competing for production there was little incentive to coordinate physical, administrative, economic and social processes. The actors' role and function in the supply network were in fact unclear.

Economic incentives for sharing skills and knowledge were unclear as the own production site's performance was one of several, sometimes competing, inputs to the common owner, C-Worldwide. Socially, the Chinese organisation and our focal company were distant from each other - the parallel supply networks spoke different languages, had different goals, etc. Some activities were integrated to some extent, such as information-sharing, joint planning, and coordination of interdependent flows because these needed to function on the most basic level. In the performed coordination and design of parallel supply networks, knowledge of logistics structure and access to networks became a valuable knowledge that was developed. In 2009, the economic downturn created anxiety about the production sites' survival. It became a question of utilising the sites' capacity and improving the cash flow. A political game to 'win' production to the home country production site at C-Worldwide's board meeting was won by our focal company. However, with a major downturn in sales there was little to celebrate. The expensive components and platforms for the high-end segment were a burden with a decreasing cash flow. And, the parallel and overlapping Chinese and Swedish supply networks were still in place. As long as production sites were competing for production there was little incentive to coordinate physical, administrative, economic and social processes.

On a strategic level and on a middle-management level the goals became slightly confused. If the production transfer succeeded then our focal company might lose control and the decision right of where all production takes place. If the Swedish production site got too small then the capability to develop new models and innovative solutions would decrease over time, which in turn would weaken their market offer. Thus strategically, the involvement of the sister company in the outsourcing process was more ambiguous than a greenfield process. The two worlds of the sister company and our focal company differed with regard to what was important and how to do it. The core reason to produce in a lowcost country was to lower costs. The same standards for quality had to apply regardless of production site to maintain the brand's core value. However, the different companies' middle managements had different frames of references on how to do this. Matching these was difficult based on the strategic ambiguity. The uncertainty of how the process 
would be coordinated created frustration but was also a breeding ground for learning. The other's way of doing gave insights to their own way of doing. The OEM started to question whether all special components had to be special because these impeded the ramp up of production and delimited the choice of suppliers. As it was, components might travel an extra turn around the world, as only suppliers with a close relationship with our focal company were able to produce them. The sister firm had questioned its (and the supply network's) biased focus on costs because of its burden on the product image. For high-end products the production process was important because it determined the result. A similar difference applied to the distribution: C-Worldwide was used to arranging low-price mass distribution, while high-end products needed to be shipped to individual customers. Next Investor's low-cost demands forced our focal company to use slower and cheaper logistics modes than they preferred.

The outsourcing process achieved coordination of production, sharing knowledge of how to produce and tools for production. The quality learning process proceeded effectively. The order-to-delivery process needed further coordination. The outsourcing process had not developed the production and distribution of the high-end machine into a situation where the OEM and the customers were fully satisfied. In the future, the OEM would prefer to address strategic coordination in order to develop along their preferred path of being high-end machine manufacturers.

In all, some resources seemed to play a pivotal role in the outsourcing process: production sites, R\&D capability, knowledge of logistics structure and access to a supply network of lowcost suppliers and developmental suppliers. These resources were used as they historically had been used except when there was a forcing element (such as a board decision to employ another production site). The learning aspect was operational in character rather than integrative. A lack of coordination had burdened the actors. Over time problems emerged that were discussed internally. As those who were involved had little power to change the situation, these discussions remained unsettled. The coordination was weak in the C-Worldwide network and lacked inter-organisational as well as organisational project groups to fuel the development.

\section{Analysing development of outsourcing from an innovative process perspective}

In the empirical description we described the OEM's outsourcing process development. It should be clear that the actors needed to continuously respond to and interpret dynamics in the environment - the interpretations that they had made and what interpretations others made, such as Next Investor or the Chinese counterparts in line with the Flint et al. (2005) discussion. Such social aspects have major implications in any social phenomenon because the controversial forces need to be made sense of in order to understand the phenomenon of outsourcing as an innovative process. Innovations are highly likely to fail and the forthcoming analysis could serve as a scheme for reflection. 


\section{The first phase of outsourcing}

Staging innovative outsourcing included problematisation and small-scale resource mobilisation (Hoholm, 2009): traditionally, the OEM's purchasing function was not seen as strategically important but more of a services function to product development and marketing functions. As the new CEO started, new opportunities were seen to lower the costs by developing the supply network by (industrialising the production and outsourcing some production), which would vitalise the business model (Kuratko \& Audretsch, 2009).

Knowledge exploration of outsourcing included learning by doing by including the network to learn about social possibilities to find suppliers, technical reformulations and economic relations of importance. The OEM's outsourcing initiative was based on the proposition that efficiency as well as effectiveness could be improved by working with sourcing in another way. In the process, some agents and suppliers were involved to refine the product structure in order to increase efficiency; an employee was setting up a supplier network in order to be effective with regard to the demands placed on sourcing. The relationships with Chinese suppliers were close as the employee put much emphasis on 'living in' the demands of each relationship. In this learning phase the purchasing function at the OEM considered the proposition to be engaging and exciting and thus involved suppliers engaged for future business. The outsourcing idea developed by inter-organisational learning in line with the propositions of Flint et al. (2005). During the knowledge exploration processes the aim was to create knowledge, which might increase rather than decrease uncertainty and complexity as more possibilities opened up; it is in the interaction between mobilisation and exploration processes that the project is compromised in a certain direction (Hoholm 2009: 246).

The mobilisation of actor-networks was a pragmatic process of mobilising the time, space, actors and resources in order to start the exploration and realisation of the innovation (to mobilise power over resources and decisions) (Hoholm, 2009). The CEO opened up to outsourcing and slowly the process took shape as the supply network developed through the employee in China. The OEM had an ongoing good relationship with a logistics provider that was willing to engage in line with the extra demands; handling the transportation and in the future more advanced third party logistics services. The mobilisation processes of actornetworks were characterised by uncertainty from the beginning; then, as actor-networks developed a degree of certainty had to be presumed (Hoholm 2009: 246).

In summary, the first phase of the innovation involved substantial interaction and confrontation and was appreciated as demanding and positive. The OEM explored knowledge and mobilised the actor-network simultaneously (sometimes with problems). The OEM's logistics function could not develop the explored knowledge of outsourcing to China with its third party logistics firm. They needed to practise and learn more about demands of customers, possibilities, problems, etc. This unwillingness to bring in a third party was also related to 
the uncertainty of what to expect - is it the right quality and the right package? - and to the feedback loop of how to better formulate their demands and prescriptions in their orders. The new CEO brought strategic sourcing into the OEM, partly by supply base reduction and partly by outsourcing. These two processes interacted and complemented each other as they were practised. R\&D-related suppliers were kept while other relationships were complemented. Also the knowledge exploration performed by the employee in China facilitated both continued learning and practising, because he had close relationships with the OEM as well as with Chinese suppliers. These outcomes were situational (cf. Nordigården, 2007), which matters in order to understand how interdependencies are at work and instantiated in the development.

However, this innovation process was not a stand-alone process. A big company that owned a huge actor in the same industry, but in another market segment, acquired the OEM. This forced the innovation process to be re-staged.

\section{The next phase of outsourcing}

The new governor brought with them new ideas and a parallel supply network involving a Chinese production site. The cost structure was now seen in another perspective, i.e. in the wider networks perspective. Outsourcing as an idea was approved but the synergy of the acquisition was also an important process. Therefore C-Worldwide's production site was involved, which was a decision that led to another type of problematisation and large-scale mobilisation of resources, as these should produce lower-end types of the platform as a sole supplier.

Further knowledge had to be explored: The Chinese production site mass produced lowcost machines that differed a lot from the high-end machines. What knowledge did they have? The OEM wanted to learn more about their expertise related to efficiency. However, the quality and working methods were not acceptable to the OEM's needs. And the Chinese production site had little insight into their business model and were poorly incentivised to learn more because the outsourced production was too small to make a difference in their yearly production. Was the Chinese production site actually a cooperating partner or a competitor in Next Investor's portfolio of sites? Next Investor had a short-term perspective; they had stated that they would sell the OEM within a few years - maybe they would close down some production sites? Thus, at the same time that the OEM had to make sense of the development they had to change the direction of their outsourcing process. Operationally, the employee with China experience, together with people from production, exchanged ideas, and transferred necessary production equipment and production methods to the Chinese site. They experienced that the supplier was huge in relation to them but was willing to learn from them despite the difference in size. As the production transfer proceeded both parties learned by doing. The OEM learned, inter alia, that they needed 
to specify explicitly what they wanted and that process quality was difficult to achieve from the supplier who was accustomed to product quality, i.e. they checked and ensured the product instead of the process.

Actor-networks needed further mobilisation (in line with Flint et al., 2005). At this point, the actor-network was pre-set at least to some degree. The employee in China had to move back to Sweden and work with transfer of production from Sweden to China. A plan of necessary steps was developed and problems in the transfer were handled along the way as both parties needed to fulfil their obligations and wished to learn more about the part unfamiliar to them. When we interviewed these parties they had a common sense of cost vs quality, and they feared that the high-end brand value would decrease over time due to country of origin. But their view of the supply network, such as how to use middlemen, the possibility of using local low-cost sourcing despite a need for 'expert' suppliers was unsettled. Also, a strategic inertia appeared as the issue of how to take advantage of the overlapping network was not delegated. C-Worldwide's top management team used consultants in order to address some of these questions but that initiative was not included in the outsourcing process. At the same time as the OEM tried to mobilise the new actor-network, the market dropped for all types of machines (the 2008 financial crisis) but in particular for high-end machines. The unclear objectives, the competing atmosphere among the production sites and the changed demand for products reversed the strategic development of OEM's outsourcing to merely coping (cf. Trent and Monczka [2005]) with ambiguous goals, changed circumstances and declining faith in the idea, different resources interfered in the re-mobilisation of the actor-network. The different actors drew on available resources and the effect was that the actor-network could no longer discern the benefit of outsourcing.

The crisis was a major drawback for Next Investor's plan to sell the OEM (and potentially also C-Worldwide). They started to discuss the value of parallel networks, which became a political agenda. The OEM regarded this development as a betrayal and they started to demobilise the actor-network and tried to take back some of the production by referring to past problems and future threats.

In summary, the next phase of interaction and confrontation illustrated that an innovation process cannot be isolated from other (innovation) processes in-house or in the supply network, which is of special importance to logistics and SCM-related innovation processes (Flint et al., 2005; Kuratko \& Audretsch, 2009). Next Investor swapped the outsourcing into a very different kind of process when it involved C. Governance was evolving with a set of interconnected and interacting processes that mutually influenced each other. The confrontation based on different influences along the development re-directed objectives, processes and outcomes of the outsourcing. 
Different sub-processes interacted, such as R\&D demands and using different production sites. Also of especial importance to logistics and SCM innovation processes, Hoholm (2009:292) argues, is that new user-producer relationships are hard to establish during innovation, and they will be fragile due to a lack of intertwined interests and resources. The $C$ network and the OEM had a genuine interest and explored knowledge together but they were not interdependent. Instead they were forced into a competitive situation. In line with Moses (2009), the outcome of a make-or-buy decision affects competitive advantage as perceptions of the product might change and the production and distribution processes are changed, and the strategic development at least to some extent is forced into a direction that leads to changes in internal and external relations. Moses found that at least eight characteristics shaped this process: organisational position, time for development, complexity of products, designation of process owner, make-or-buy strategy, production systems, customer relations and supplier relations. To the OEM outsourcing these contributed to the social situatedness and enforced confrontation in the happening, and further outsourcing development was frozen.

\section{The interactive process model applied}

We have analysed the development in two turn-taking phases. By necessity, processual analysis is done in hindsight and the extra insight gained by the practice view is that the analysis is bounded by its development and shows results 'along the way'. In this way the practice approach complements other process studies. It takes seriously the windy road most innovators must take to get results, by being an open inquiring conceptual model (see Table I) rather than a closed prescriptive conceptual model. It is an analytical framework for projection and evaluation of innovation processes and a tool for close monitoring of innovation.

Table I: Open analytical model for projection and evaluation of an innovation development

\begin{tabular}{|l|l|l|}
\hline Turn-taking by interactions and confrontations & Phase $_{\mathbf{n}}$ & Phase $_{\mathbf{n + 1}}$ \\
\hline What is the existing actor-network? & Reflection and projection of capabilities, willingness \\
What is the existing knowledge? & and understanding in each phase. Especially \\
Where to go? & evaluate who is in the actor-network and if powerful \\
Where have we ended up? & $\begin{array}{l}\text { and relevant actors are too loosely engaged and } \\
\text { sufficiently understood. }\end{array}$ \\
\hline
\end{tabular}

In order to understand the development it is important to acknowledge that different reasons for actions meet in one outsourcing project. These different sub-processes might be seen as temporary sub-optimising solutions to a particular problem and form a social situatedness to the outsourcing process. The OEM's first and second phase of outsourcing changed dramatically over time in content. Thereafter, it continued with an attempt to 
withdraw the outsourced production because there were stronger forces to relocate the production back in Sweden in order to avoid lay-offs. Despite the withdrawal the OEM had performative outcomes, such as advanced coordination of production, cooperative production, knowledge sharing of quality, a deeper understanding of the order-to-delivery process including distribution, interest in strategic development regarding the purchasing function and the supply network because reflection on what happened breeds new and refined questions. The social situatedness and performative outcomes are important to the Flint et al.'s logistics innovation process highlighting negotiating, clarifying and reflecting activities followed by inter-organisational learning (see Figure 1). However, negotiation and clarification are dialogical and we learned about the pivotal role of the owner in this case as the outsourcing project dramatically changed its long-term objectives. Actually, the longterm and short-term objectives became controversy forces. A critical evaluation of contrary forces is important in order to understand action, which is key in practice studies. It is of particular interest to apply such studies to logistics innovation because of relevance to practitioners. It is process research that is purposeful for change/stability studies, where events, activities, choices and above all, actors, are seen as important to the explanations that are expressed. Explanations have, in relation to other process studies, a fairly high accuracy, and fairly low simplicity and generality (Langley, 1999).

It is necessary to make sense of controversial forces in order to understand the phenomenon of outsourcing as an innovative process. Innovations are highly likely to fail and the analysis has followed the 'happening' by reflection. We have critically evaluated and brought in governance, social situatedness and performative outcomes as important attributes in order to understand outsourcing as an innovation process.

\section{CONCLUSIONS}

We have studied the development of an outsourcing process based on an analytical scheme of innovation processes. The analysis recognises that the innovation process is interconnected and heterogeneous; it draws on interaction and confrontation in the development. The approach and the results are a contribution to logistics and SCM research, not only by addressing logistics innovation, but by engaging in the social aspects of innovation and the role of interactions and reflexivity among the actors as much as innovation stages and innovations themselves (Flint et al., 2005). Instead of stages and outcomes of innovation processes, our approach illustrates the complexity inherent in a myriad ideas and actions that add to (or withdraw from) the innovation process over time. The case and, even more so, the analysis illustrate the dynamics and complexities and serve as a source of reflection for practical implications. The happening in this case is socially situated and some of its characteristics are likely to exist in other innovation processes. Knowledge exploration to make sense of the past, present and future is an output and input to mobilisation of actor- 
networks and vice versa. We developed an open analytical framework (Table I) to increase the applicability of the approach.

Governance was important to the development of outsourcing, which was unexpected as it is seldom mentioned in logistics and SCM literature. Instead top management support is mentioned as an impetus to any strategic logistics initiative. However, top management support is not a solid variable; it might be more or less, change over time, and depend on the development of other initiatives. Our case of outsourcing had top management support but the objectives changed. Competing objectives are a source of contrary forces in innovation processes (Hoholm, 2009) and a likely reason for turn-taking in the process. A part of top management became involved while another part was resistant. A new owner imposes a new network that will influence the existing network implicitly or explicitly. We learned that as the networks glided into each other (the Chinese production site became the supplier) the actor-network took another form. At least to some extent, the social situatedness of the outsourcing process changed in characteristics, for example, organisational position, time for development, complexity of products, designation of the process owner, make-or-buy strategy, production systems, customer relations and supplier relations (Moses, 2009). The initial idea (the first phase of outsourcing) was mostly in conflict with the new owner's ideas. Hoholm (2009: 269) describes that constructing an actor-network around a new idea is an exercise in connecting actors, networks, resources and ideas in a creative way in order to produce power effects to pave the way for the innovation and translate different interests into the innovation. Unless the OEM's outsourcing ideas are converged with the new owner's the latter is likely to dominate, which also was illustrated by the case. Performative outcomes were important driving forces and hindrances in the development.

Practice lenses, such as the innovation model or the actor-network theory, are interesting to apply to logistics innovation because of relevance to practitioners. Process research is applicable to change/stability studies, where events, activities, choices and above all, actors, are seen as important to the expressed explanations. In relation to other process studies its accuracy is fairly high, while its simplicity and generality is fairly low (Langley, 1999). Outsourcing models in the literature often consist of conceptual pieces that make sense in relation to social mechanisms and, thereby, more informed cause-effect relationships are possible by a practice lens. Also a social practice perspective's generalisations are situated in time and context. Contextual generalisations are made in the reader's instantiation of the results. Questions and reflections based on this study (see Table $l$ ) increase understanding of turn-taking in other innovation processes. Turn-taking is the general social part of an innovation process that is reliant on contextual interactions and confrontations and can be done more or less thoughtfully. 


\section{REFERENCES}

Agndal, H. 2004. Internationalisation as a process of strategy and change: A study of 16 Swedish industrial SMEs. Dissertation, Jönköping International Business School Jönköping.

Agndal, H. \& Nordin, F. 2009. Consequences of outsourcing for organizational capabilities: Some experiences from best practice. Benchmarking, 16(3), 316-34.

Alvesson, M. \& Kärreman, D. 2007. Constructing mystery: Empirical matters in theory development. Academy of Management Review, 32(4), 1265-81.

Alvesson, M. \& Sköldberg, K. 2008. Tolkning och Reflektion: Vetenskapsfilosofi och kvalitativ metod (2 ed.). Lund: Studentlitteratur.

Axelsson, B. \& Wynstra, F. 2002. Buying business services. Chichester: John Wiley.

Czarniawska, B. 2004. On time, space and action nets. Organization Science, 11(6), 773-91.

Flint, D.J., Larsson, E., Gammelgaard, B. \& Mentzer, J.T. 2005. Logistics innovation: A customer value-oriented social process. Journal of Business Logistics, 26(1), 113-48.

Gherardi, S. 2009. Introduction: The critical power of the 'practice lens'. Management Learning, 40(2), 115-28.

Helgesson, C.-F., Kjellberg, H. \& Liljenberg, A. 2004. Den där marknaden: Om utbyten, normer och bilder. Lund: Studentlitteratur.

Hoholm, T. 2009. The contrary forces of innovation: An ethnography of innovation processes in the food industry. Dissertation, BI Norwegian School of Management, Oslo.

Kjellberg, H. \& Andersson, P. 2003. Where is the action? The reconstruction of action in business narratives. In Woodside, A.G. (Ed.), Evaluating marketing actions and outcomes (Vol. 12, pp. 13-58). Oxford: Elsevier.

Kuratko, D.F. \& Audretsch, D.B. 2009. Strategic entrepreneurship: Exploring different perspectives of an emerging concept. Entrepreneurship Theory and Practice, 33(1), 1-17.

Langley, A. 1999. Strategies for theorizing from process data. Academy of Management Review, 24(4), 691-710. 
Latour, B. 1987. Science in action: How to follow scientists and engineers through society. Cambridge, MA: Harvard University Press.

Mintzberg, H. \& Waters, J.A. 1985. Of strategies, deliberate and emergent. Strategic Management Journal, 6(3), 257-72.

Mintzberg, H. 1994. The rise and fall of strategic planning. New York: Free Press.

Moses, A. 2009. Designing and managing cross-functional make or buy decision processes. Dissertation, Chalmers University of Technology Göteborg.

Nordigården, D. 2007. Outsourcing in the wood product manufacturing sector A combined customer and supplier perspective. Dissertation, Linköping University Linköping.

Pettigrew, A.M. 1997. What is a processual analysis? Scandinavian Journal of Management, 13(4), 337-348.

Rogers, E.M. 1995. Diffusion of Innovations (4 ed.): Free Press.

Schatzki, T.R. 2000. Practice theory. In Schatzki, T. R., Knorr-Cetina, K. \& Savigny, E. (Eds.), Practice turn in contemporary theory (pp. 10-23): Routledge.

Trent, R.J \& Monczka, R.M. 2003. Understanding global sourcing. International journal of Physical Distribution \& Logistics Management, 33(7), 607-69.

Trent, R.J. \& Monczka, R.M. 2005. Achieving excellence in global sourcing. MIT Sloan Management Review, 47(1). 